\title{
Silica-scaled Chrysophyceae and Synurophyceae from Nigeria. III. Chrysophytes from rivers of Edo State
}

\author{
Daniel E. WuJeK ${ }^{1}$, Medina O. KadiRI ${ }^{2} \&$ Ryan M. DzIEDzIC ${ }^{1}$ \\ ${ }^{1}$ Department of Biology, Central Michigan University, Mt. Pleasant, MI 48859, USA; \\ e-mail:wujek1de@cmich.edu \\ ${ }^{2}$ Department of Botany, University of Benin, Benin, Nigeria
}

\begin{abstract}
A total of 18 species of silica-scaled chrysophytes (Chrysophyceae: one species each in Chrysosphaerella, Spiniferomonas, and Paraphysomonas; Synurophyceae: 11 Mallomonas spp. and four Synura spp.) was recorded from river samples collected in Edo State, Benin, Nigeria, from both dry and rainy seasons in 2003. Identifications were based on transmission electron microscopy. Five are new records for Nigeria, including four being newly reported for Africa. Two further species could not be identified.
\end{abstract}

Key words: Africa, Chrysophyceae, silica-scaled chrysophytes, Synurophyceae

\section{Introduction}

The Chrysophyceae and Synurophyceae, characterized by an exogenous siliceous envelope composed of scales and/or bristles have long been recognized as important indicators of environmental conditions. Light microscopy-based identifications are of limited value as electron microscopy (EM) usually is necessary to distinguish sufficient structure for species identification in the scaled chrysophytes (KRISTIANSEN 1979).

The Nigerian freshwater algal flora, and silica-scaled chrysophytes in particular (classes Chrysophyceae and Synurophyceae), is poorly documented. Compared to the electron microscopic (EM) studies elsewhere in Africa (Chad Republic, Kenya, Madagascar, Botswana, and Zimbabwe - see WUJEK et al. (2003/2004) for review), only two EM investigations of the chrysophyte flora of Nigeria have been published (WuJEK \& OGUNDIPE 2003; WuJeK et al. 2003/2004). African chrysophyte studies in general have lagged behind those for the Americas, Europe, and Asia (KaDIRI 1992, 2004; JANATKOVÁ \& NĚmecová 2009). CRonberg (1988, 1989 , 1996) summarizes the literature on the tropics and more recent literature citations may be found in
Hansen (1996a), Wujek \& Moghadan (2001) and KRISTIANSEN (2002).

In this study, the silica-scaled algal flora from samples collected in both dry and wet seasons in 2003 from ten river locations, Edo State, Nigeria, were examined using transmission (TEM) and scanning (SEM) electron microscopy. Of all the sampling sites, only Ikpoba Reservoir, dammed from the Ikpoba River, has a published phytoplankton record. This includes desmids (Kadiri 1988, 1993a, b, 1996; Kadiri \& Opute 1989), euglenids (Kadiri \& OpUte 2000) and diatoms (Kadiri 2003; Kadiri \& OpUte 2003).

\section{Material and methods}

Phytoplankton samples collected with a $20 \mu$ m plankton net were made from ten different river locations, Edo State, Nigeria (Fig. 1, Table 1: Ovia, Nikorogha, Orionmwon, Okomu, Gelegele, Ikpoba, Ogba, Ugonoba, Ogbese, and Okokhou Rivers; the latter eight were collected twice, both in the dry season, February, and rainy season, September, 2003 while the first two were sampled only in the dry season). Preparations and observations were as previously described (WUJEK \& OGUndipe 2003). All identifications were based on TEM. None of the measured ecological parameters correlated significantly with individual taxa or taxa number. 


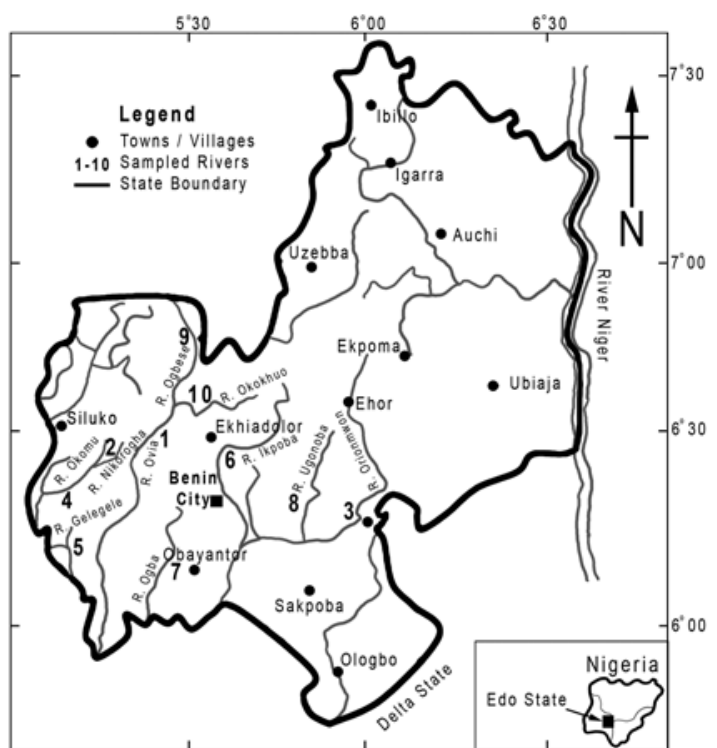

Fig. 1. 2003 river sampling sites, Edo State, Nigeria.

\section{Results and discussion}

Eighteen species of silica-scaled chrysophytes were found during this investigation. The list of taxa (Table 2) includes 11 Mallomonas taxa, four Synura taxa, and one species each of Chrysosphaerella, Spiniferomonas, and Paraphysomonas. The seven taxa newly reported for Nigeria are illustrated (Figs 2-6, 8-9), including two unidentified Mallomonas taxa (Figs 5,6). The scales of taxa not illustrated fell within the morphologies of those illustrated in the literature.

Species richness ranged from one to ten species (Table 2), the highest being in the Gelegele River dry season sample. Low richness corresponds to other studies from lotic habitats. Four samples from two dates, all from the rainy season (5R, 7R, 8R, 10R), did not yield any scaled chrysophytes. Four sampling date's yielded only one taxon each (Table 2: 3R, 4R, 6D, 9D). In our study, $83 \%$ of the samples contained at least one scaled chrysophyte, much different than Cronberg's (1996) study of nearly 350 plankton samples of which only $20 \%$ contained scaled chrysophytes. She did, however, observe 24 taxa in contrast to our 18. In our study as in the Cronberg (1996) study, Mallomonas, followed by Synura, were the most common genera. Unlike the more extensive African studies of CRONBERG (1996) and HANSEN (1996a, 1996b), our study did not find the single species representing the genus Chrysodidymus.
Sampling sites contained at least one taxon, either during the dry or rainy season (Table 1). Examination of greater than 100 published papers describing silica-scaled floras around the world, all except one from Florida, U.S.A. WUJEK \& Siver (1997), report lotic habitats as not being very diverse. The Gelegele River Dry Season sample had ten taxa. All our other samples each had four or less taxa (Tables 1,2). Indeed, most of the taxa were observed from the dry season samples (Tables 1,2). The dry season species richness may be due to generally higher turbidities, lower flow rates and $\mathrm{pH}$ and elevated conductivities. The rivers were mildly acidic to acidic $(\mathrm{pH}$ 6.8-5.1) and low in nutrients with conductivities ranging from $12-82 \mu \mathrm{S} . \mathrm{cm}^{-1}$ (Table 3).

The most frequently observed taxa were Paraphysomonas vestita and Synura echinulata. Ten of the taxa were observed only once (Table 2). Six taxa, including two unidentified Mallomonas taxa, are newly reported for Africa: Mallomonas doignonii var. doignonii, M. parvula, M. paxillata, Mallomonas sp. 3, Mallomonas sp. 4, and Synura leptorrhabda (Figs 2-6, 8); in addition, Spiniferomonas septispina is newly reported for Nigeria (Fig. 9). The single scale identified as Mallomonas sp. 3 (Fig. 5) closely resembles the body scale of $M$. inornata Nicholls, a taxon reported only from North East America. The only scale of Mallomonas sp. 4 (Fig. 6) does not appear to resemble any described Mallomonas taxon. Two of the species observed by WUJEK \& OGUNDIPE (2003) were not observed in this study, all Mallomonas species (M. portae-ferreae, M. stellata). Another Mallomonas taxon observed, $M$. matvienkoae var. matvienkoae, is the most widely reported African silica-scaled chrysophyte. It was our second most observed taxon with Synura echinulata being the most widely distributed (Table 2).

We report the third occurrence for Africa and the second for Nigeria of Mallomonas lemuriocellata (Fig. 7) originally described by Hansen (in Hansen \& Kristiansen 1995) from Madagascar. It was reported previously from Nigeria from Lekki Lake (WUJEK et al. 2003/2004).

It is not possible from this short list of species to make any comprehensive claims about the distribution of Nigerian scaled chrysophytes. More collections are needed from other Nigerian sites and from different seasons of the year to allow compiling a more complete list of the 
Table 1. Benin Region, Edo State, Nigeria, silica-scaled chrysophyte sampling sites in 2003.

\begin{tabular}{lllll}
\hline Locality & Coordinates & Date of sampling & $\begin{array}{l}\text { Species richness } \\
\text { Dry/Rainy }\end{array}$ \\
\hline 1. Ovia River & $6^{\circ} 34^{\prime} 10^{\prime \prime} \mathrm{E} ; 5^{\circ} 31^{\prime} 52^{\prime \prime} \mathrm{N}$ & 13.2. & 4 \\
2. Nikorogha River & $6^{\circ} 14^{\prime} 45^{\prime \prime} \mathrm{E} ;$ & $5^{\circ} 21^{\prime} 46^{\prime \prime} \mathrm{N}$ & 14.2. & 2 \\
3. Orionmwon River & $6^{\circ} 13^{\prime} 05^{\prime \prime} \mathrm{E} ;$ & $5^{\circ} 56^{\prime} 10^{\prime \prime} \mathrm{N}$ & $13.2 . ; 19.9$. & $4 / 1$ \\
4. Okomu River & $6^{\circ} 15^{\prime} 36^{\prime \prime} \mathrm{E} ;$ & $5^{\circ} 06^{\prime} 10^{\prime \prime} \mathrm{N}$ & $07.2 . ; 19.9$. & $3 / 1$ \\
5. Gelegele River & $6^{\circ} 09^{\prime} 15^{\prime \prime} \mathrm{E} ;$ & $5^{\circ} 21^{\prime} 00^{\prime \prime} \mathrm{N}$ & $13.2 . ; 20.9$. & $10 / 0$ \\
6. Ikpoba River & $6^{\circ} 21^{\prime} 25^{\prime \prime} \mathrm{E} ;$ & $5^{\circ} 38^{\prime} 20^{\prime \prime} \mathrm{N}$ & $06.2 . ; 19.9$. & $1 / 3$ \\
7. Ogba River & $6^{\circ} 17^{\prime} 05^{\prime \prime} \mathrm{E} ;$ & $5^{\circ} 35^{\prime} 10^{\prime \prime} \mathrm{N}$ & $06.2 . ; 19.9$. & $2 / 0$ \\
8. Ugonoba River & $6^{\circ} 19^{\prime} 05^{\prime \prime} \mathrm{E} ;$ & $5^{\circ} 50^{\prime} 10^{\prime \prime} \mathrm{N}$ & $06.2 . ; 19.9$. & $3 / 0$ \\
9. Ogbese River & $6^{\circ} 45^{\prime} 00^{\prime \prime} \mathrm{E} ;$ & $5^{\circ} 33^{\prime} 15^{\prime \prime} \mathrm{N}$ & $13.2 . ; 19.9$. & $1 / 3$ \\
10. Okokhuo River & $6^{\circ} 34^{\prime} 15^{\prime \prime} \mathrm{E} ;$ & $5^{\circ} 36^{\prime} 10^{\prime \prime} \mathrm{N}$ & $17.2 . ; 19.9$. & $2 / 0$ \\
\hline
\end{tabular}

Table 2. Benin Region, Edo State, Nigeria, silica-scaled chrysophytes [(*) new record for Africa; $\left(^{* *}\right)$ new for Nigeria; (D) dry season, (R) rainy season; localities see Table 1].

\begin{tabular}{|c|c|}
\hline Taxon & Locality \\
\hline \multicolumn{2}{|l|}{ Chrysophyceae } \\
\hline Chrysosphaerella annulata KRISTIANSEN et D. ToNG & $5 \mathrm{D}$ \\
\hline **Spiniferomonas septispina K.H. NichOLLS & $6 \mathrm{R}$ \\
\hline Paraphysomonas vestita (StOKeS) de SAEDELEER & $\begin{array}{l}1 \mathrm{D}, 3 \mathrm{R}, 4 \mathrm{D}, 4 \mathrm{R}, 5 \mathrm{D}, 6 \mathrm{D}, 7 \mathrm{D}, 8 \mathrm{D}, 9 \mathrm{D} \text {, } \\
10 \mathrm{D}\end{array}$ \\
\hline \multicolumn{2}{|l|}{ Synurophyceae } \\
\hline Mallomonas cyathellata var. kenyana WUJEK et AsMUND & $3 \mathrm{D}, 5 \mathrm{D}$ \\
\hline *M. doignonii var. doignonii Bourrelly em. Asmund et CronberG & 1D \\
\hline M. lemuriocellata P. HANSEN & $5 \mathrm{D}, 10 \mathrm{D}$ \\
\hline \multicolumn{2}{|l|}{ M. matvienkoae var. matvienkoae (MATVIENKO) } \\
\hline ASMUND et KRISTIANSEN & $1 \mathrm{D}, 2 \mathrm{D}, 5 \mathrm{D}$ \\
\hline M. multisetigera DÜRRSCHMIDT & $2 \mathrm{D}, 5 \mathrm{D}$ \\
\hline *M. parvula DÜRRSCHMIDT & $4 \mathrm{D}$ \\
\hline *M. paxillata (D.E. BradLey) L.S. PÉTerfi et Momeu & $9 \mathrm{R}$ \\
\hline M. peronoides (K. Harris) L.S. PéTERFI et MOMEU & $1 \mathrm{D}, 5 \mathrm{D}, 6 \mathrm{R}$ \\
\hline M. rasilis DÜRRSCHMIDT & 9R \\
\hline *Mallomonas sp. 3 & $3 \mathrm{D}$ \\
\hline *Mallomonas sp. 4 & $5 \mathrm{D}$ \\
\hline
\end{tabular}


Table 2 Cont.

\begin{tabular}{ll}
\hline Synura curtispina (J.B. Petersen et J.B. Hansen) Asmund & 3D, 5D \\
S. echinulata KorshiKov & $3 \mathrm{R}, 4 \mathrm{D}, 6 \mathrm{R}, 7 \mathrm{D}, 8 \mathrm{D}, 9 \mathrm{R}$ \\
*S. leptorrhabda (Asmund) K.H. Nicholls in K.H. Nicholls et & \\
GerRath & 8D \\
S. spinosa KorShiKov & 5D \\
\hline
\end{tabular}

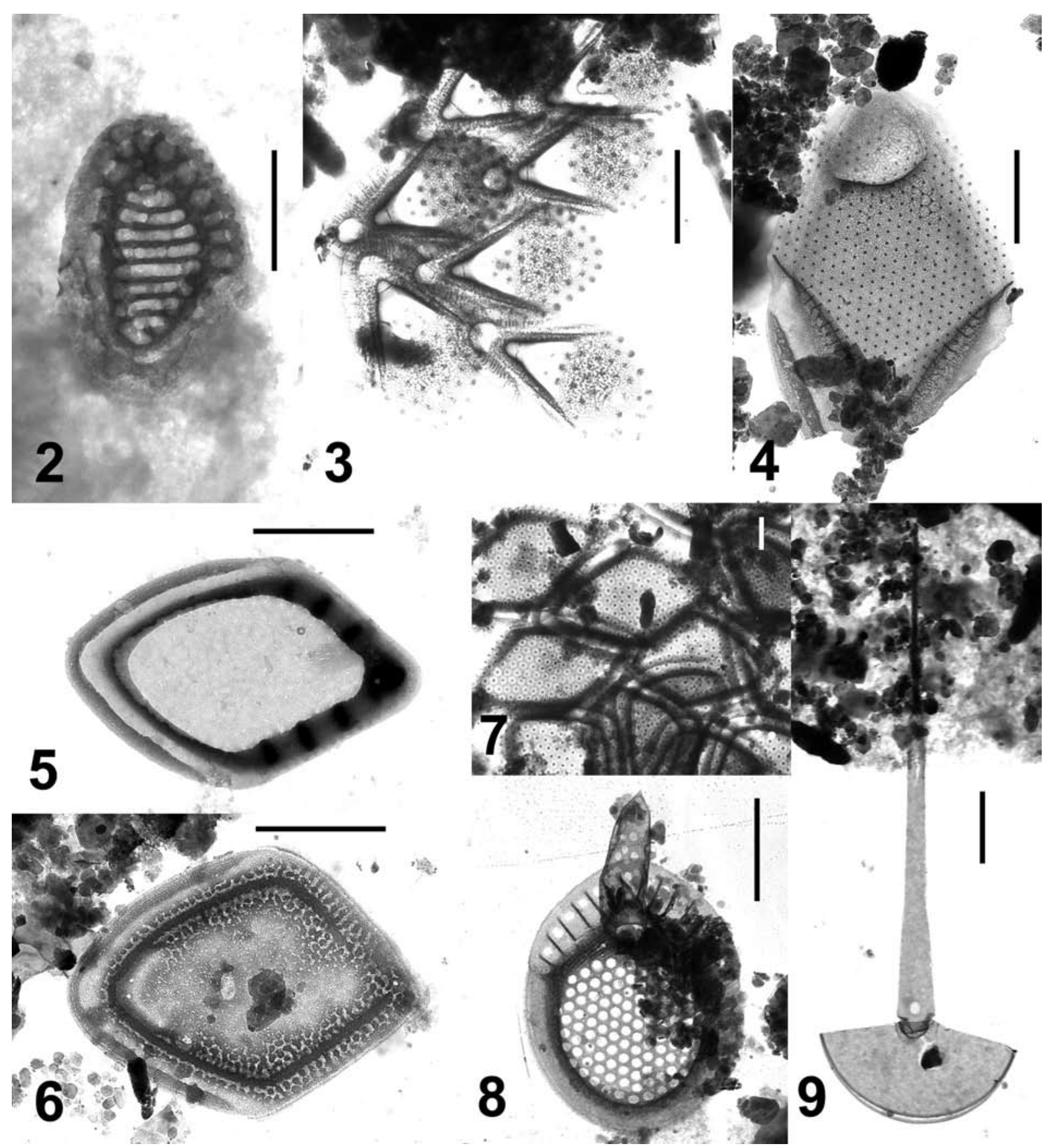

Figs 2-9. (2) Mallomonas doignonii var. doignonii: body scale; (3) M. parvula: body scales; (4) M. paxillata: body scale; (5) Mallomonas sp. 3: scale; (6) Mallomonas sp. 4: scale; (7) M. lemuriocellata: body scales; (8) Synura leptorrhabda: body scale; (9) Spiniferomonas septispina: spine scale. Scale bar $1 \mu \mathrm{m}$. 


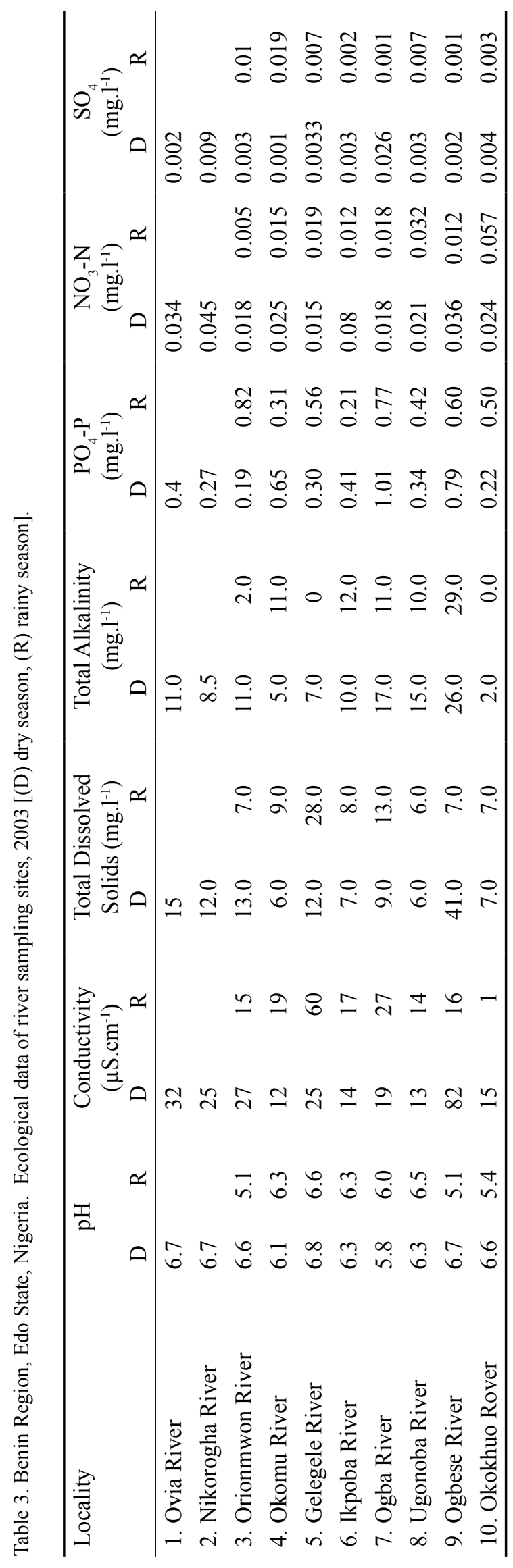

silica-scaled chrysophyte flora. Three EM silicascaled chrysophyte studies of Nigerian samples have been conducted to date resulting in 31 observed taxa. These 31 species include only two, $M$. lemuriocellata and $P$. nigeriensis, which have not also been reported from temperate regions (see Cronberg 1989; Kristiansen 2001; WuJeK et al. 2003/2004). As HANSEN (1996a) stated "many unsolved questions remain regarding biogeography and ecology of the silica-scaled Chrysophyceae and Synurophyceae in the tropics."

\section{Acknowledgements}

We thank G. Williams for the preparation of the carbon-coated grids, B. Roberts for assistance in the preparation of the plates and Dr. Jørgen Kristiansen for commenting on some of our micrographs. Festus Arijiode is also gratefully acknowledged for his assistance in the collection of samples.

\section{References}

Cronberg, G. (1988): Mallomonas stellata, a new silica-scaled chrysophycean from Zimbabwe. Kirkia 13: 143-152.

Cronberg, G. (1989): Scaled chrysophytes from the tropics. - Beih. Nova Hedwigia 95: 191-232.

Cronberg, G. (1996): Scaled chrysophytes from the Okavango Delta, Botswana, Africa. - Beih. Nova Hedwigia 114: 91-108.

Hansen, P. (1996a): Silica-scaled Chrysophyceae and Synurophyceae from Madagascar. - Arch. Protistenkd. 147: 145-172.

Hansen, P. (1996b): Spiniferomonas cetrata sp. nov. (Chrysophyceae), from an event of stomatocyst formation in the tropics. - Beih. Nova Hedwigia 114: 71-80.

Hansen, P. \& Kristiansen, P. (1995): Mallomonas madagascariensis, M. lemuriocellata and $M$. crocodilorum (Synurophyceae), three new species from Madagascar. - Nord. J. Bot. 15: 215-223.

JANATKOVÁ, K. \& NĚMcovÁ, Y. (2009): Silica-scaled chrysophytes of Southern Bohemian water bodies, including Mallomonas conspera Dürrschmidt with occurrence so far reported from Japan and New Zealand. - Fottea 9: 9399.

KADIRI, M.O. (1988): A taxonomic study of the genus Closterium (Nitzsch. 1817) Ralfs 1848 (Desmidiaceae), with ecological notes. Tropical Freshwater Biol. 1: 71-80.

KADIRI, M.O. (1992): Freshwater algae of West Africa: A bibliography, 1956-1991. - Polsk. Arch. Hydrobiol. 39: 199-211.

KADIRI, M.O. (1993a): Records of members of the genus 
Cosmarium Corda ex Ralfs (Desmidiaceae, Chlorophyta) in a shallow West African reservoir. - Nova Hedwigia 57: 109-122.

KADIRI, M.O. (1993b): Further desmids from the Ikpoba Reservoir (Nigeria) compared with other records from Africa. - Arch. Hydrobiol./ Algological Studies 71: 23-35.

KADIRI, M.O. (1996): More desmids from the Ikpoba Reservoir, Nigeria: Comparison with other African records. - Arch. Hydrobiol./Algological Studies 80: 87-98.

KADIRI, M.O. (2003): Diatoms from Nigeria. - Arch. Hydrobiol./Algological Studies 110: 17-26.

KADIRI, M.O. (2004): African freshwater algae: A bibliographic update. - Acta Bot. Hung. 46: 179-200.

Kadiri, M.O. \& Opute, F.I. (1989): A rich flora of Micrasterias from the Ikpoba Reservoir, Nigeria. - Arch. Hydrobiol. 116: 391-399.

Kadiri, M.O. \& Opute, F.I. (2000): The Euglenoids of the Ikpoba reservoir. - Biologia 55: 351-356.

Kadiri, M.O. \& Opute, F.I. (2003): SEM observations of some noteworthy diatoms from the Ikpoba reservoir, Nigeria. - Plant Biosyst. 137: 215229.

Kristiansen, J. (1979): Problems in classification and identification of Synuraceae (Chrysophyceae). - Schweiz. Zeitschr. Hydrol. 40: 310-319.

KRISTIANSEN, J. (2001): Biogeography of silica-scaled chrysophytes. - Beih. Nova Hedwigia 122: 23-29.

Kristiansen, J. (2002): The genus Mallomonas (Synurophyceae). A taxonomic survey based on the ultrastructure of silica scales and bristles. Opera Bot. 139: 1-218.

WujeK, D.E. \& Moghadan, L.A. (2001): Scaled chrysophytes from Florida. VII. Observations on the flora from the southeast. - Florida Sci. 64: 274-282.

Wujek, D.E. \& Ogundipe, O.T. (2003): Silicascaled Chrysophyceae and Synurophyceae (Chrysophyta) from western Nigeria. - Nigerian J. Bot. 16: 108-111.

WujeK, D.E. \& Siver, P.A. (1997): Studies on Florida Chrysophyceae (Paraphysomonadaceae) and Synurophyceae (Mallomonadaceae). V. The flora of north-central Florida. - Florida Sci. 60: 21-27.

Wujek, D.E., Adesalu, T.A. \& Nwankwo, D.I. (2003/2004): Silica-scaled Chrysophyceae and Synurophyceae (Chrysophyta) from Nigeria. II. Lake Lekki. - Tropical Freshwater Biol. 13: 99-103.

(C) Czech Phycological Society

Received May 13, 2009

Accepted September 5, 2009 